\title{
The Caroline Islands
}

\section{Thomas Muir LL.D F.R.S.E.}

To cite this article: Thomas Muir LL.D F.R.S.E. (1885) The Caroline Islands, Scottish Geographical Magazine, 1:12, 634-639, DOI: 10.1080/14702548508553860

To link to this article: http://dx.doi.org/10.1080/14702548508553860

曲 Published online: 30 Jan 2008.

Submit your article to this journal 준

III Article views: 3

Q View related articles ¿ 
of the plateau sinks down into the alluvial plain formed by the river towards its mouth, where lies Asbyrgi, celebrated through all Iceland for its exquisite beauty.

From this place Thoroddsen made his way to Húsavik, and from thence to Akureyri, which he reached on the 4th of September. He had travelled for nine weeks, of which five had been spent in uninhabited parts, where his tent had been his sole shelter.

\section{THE CAROLINE ISLANDS.}

\section{By Thomas Muir, LL.D., F.R.S.E.}

THE reader who has an accurate conception of the geographical position of New Guinea, and the newly baptized Bismarck Archipelago, may readily acquire a tolerably correct idea of the whereabouts of the Caroline Islands. New Guinea, we know, lies like a gigantic saurian between Australia and the equator, stretched at full length in a N.W. and S.E. direction, its head almost just reaching the equator, and the tip of its tail going slantwise across the line of 10 degrees south latitude. Roughly speaking, then, the Caroline Islands are to the N.N.E. of New Guinea, and occupy a situation north of the equator corresponding to that which New Guinea and the Bismarck Archipelago occupy to the south, none of them quite reach ing the equator, and those which are furthest north being just beyond the line of 10 degrees north latitude. In other respects the occupants of these two belts are a wonderful contrast. New Guinea belongs to the front rank among the large islands of the world, and its neighbours of the Bismarck Archipelago are not by any means diminutive; the Caroline Islands, on the other hand, are but tiny specks dotted over a vast extent of ocean surface. Almost due north of the head of New Guinea, the sprinkling, if we may so speak, begins, giving us first the Pelew group, which, however, has been often viewed as distinct from the Carolines; then, after a break, the scattered group which includes Yap, Ngoli or Matalotes Islands, Uluthi or Mackenzie Islands, and Sorol or Philip Islands; then, after another break, a long succession of small clusters, Wolea or Ulie Islands, Swede Islands, Los Martires and Enderby Islands, Namonuito or Lütke Islands, Hogolu or Truk Islands, the Mortlock Islands, and others; then there is a break once more, and we come to the Seniavina group, of which Ponape or Puynipet is the chief ; and finally, after passing a straggler or two, we reach Kusaie or Ualan, the extreme eastermost of the long chain. In our survey, we have traversed from west to east 2000 miles of ocean, and have confined ourselves within a belt 300 miles broad at the greatest. To the west of the belt lie the most southern islands of the massive group of the Philippines; to the north of the middle of the belt lie the isles of the Marianne or Ladrone group; and to east and south-east are the Marshall and Gilbert Islands, closely resembling the Carolines themselves. Though 
there are in all somewhat over 500 of the Caroline Islands, the greater number are merely atolls. It is better to enumerate them as consisting of 48 groups, each group comprising an island and several surrounding islets. The total area is most insignificant when compared with the vast surface over which they are spread; it is not accurately known, but has been estimated at 1200 square miles-that is to say, about one-fifth of the area of Yorkshire. The largest of the archipelago is Ponape, one of the most easterly, which is compact in shape, having an area of about 14 miles square, and a coast line between 50 and 60 miles long. The next is Yap, one of the most westerly, which is rather over 20 miles long, but is narrow and deeply indented. These and three others are estimated to contain about two-thirds of the entire area of the archipelago.

The appearance and physical structure of the islands can be dealt with in very few words. Of the total 48 groups, 43 are flat and composed of coral; and five, which have just been referred to as having the greatest area, are mountainous and composed of basalt with coral round the base. In Ponape, for example, the mountains attain a height of between 2500 and 3000 feet, giving rise to pretty streams, and, being wooded to the summit, are very beautiful as seen from the sea.

The Carolines are said to have been first discovered by the Portuguese in 1525 ; the Spaniards followed in 1543 , and navigators of both nationalities frequently touched at some point of them during the remainder of the sixteenth century. Their present name was first given to them in 1686, and was in honour of Charles II. About that time, the Spaniards resident in the Philippines and the Mariannes acquired some topographical and other knowledge regarding the group; and in 1705 an imperfect map, embodying this knowledge, was sent to Pope Clement XI. Kotzebue visited them in 1817, Duperrey in 1824, and Lütke in 1827-8. To these three navigators, and to Freycinet and Dumont d'Urville, we are indebted for the first accurate accounts of the islands and their inhabitants. Several of the explorers were ignorant of the work of their predecessors ; consequently many of the groups bear two names, and some of them have three.

A most important and, as we are bound to believe, exceedingly interesting part of their past history has been lost. On more than one of them there still exist massive ruins which have been a puzzle to modern ethnologists. Ponape is in this respect the most notable. Captain L. U. Herendeen of San Francisco, who visited the island a few years ago, writes as follows:- "The island is surrounded by a reef; and between the two there is a broad ship channel. At places in the reef there are natural breaks, that serve as entrances to the harbours. In these ship channels there are a number of islands, many of which are surrounded by a wall of stone five or six feet high; and on these islands there stand a great many low houses, built of the same kind of stone as the walls about them. The natives on the island do not know when these works were built; it is so far back in the past that they have even no tradition of the struc- 
tures. Yet the works show signs of great skill, and certainly prove that whoever built them knew thoroughly how to transport and lift the heavy blocks of stone. Up in the mountains of the island there is a quarry of the same kind of stone that was used in building the walls about the islands; and in that quarry to-day there are great blocks of stone that have been hewn out ready for transportation. The natives have no tradition touching the quarry-who hewed the stone, when it was done, or why the work ceased. They are in greater ignorance of the great phenomena about them than the white man who touches on their island for a few hours for water. There is no doubt in my mind that the island was once inhabited by an intelligent race of people, who built the temples and forts of heavy masonry on the high bluffs of the shore of the island, and that, as the land gradually subsided, these bluffs became islands. They stand to-day with a solid wall of stone around them, partly submerged in water." Captain Maxwell, of H.M.S. Emerald, found, in 1881, "enclosures within enclosures-on one islet four complete squares, one within the other -with walls in some places 35 feet high and upwards of 12 feet thick, built of great basaltic prisms (many of them 12 feet by 2 feet 6 inches), laid regularly tier upon tier; each tier being at right angles to the one below, and the interstices filled in with coral and rubble." Mr. Doune, American missionary on the island, considers "the ruins to be those of old chiefs' residences, built in days when chiefs were more powerful, and the population more numerous than now." Captain Maxwell, who also visited Strong Island, found similar ruins on the small islet of Lele, where the king lives. "The walls there are some 20 feet high, having been in former times probably as high everywhere, and 12 feet thick, and are built of enormous basaltic rocks, which must have been brought from a distance, and have cost much labour and ingenuity to raise them to their present positions." Dr. Pease, of the American Mission, says that the king has always lived on Lélé; that the population, now about 300 , amounted in former times to ten times that number; and that these forts were built for royal defence, and to overawe the main island.

The climate of the Caroline Archipelago is of course tropical. There are said to be two rainy seasons, one in January, and the other in August; but it is scarcely necessary to distinguish the seasons into wet and dry where the climate is so prevailingly moist. Europeans find it far from disagreeable, and it is not known to be unhealthy, unless in certain low situations near the coast.

Many of the islands are wonderfully fertile, producing all the usual fruits and vegetables of Micronesia in abundance-bread-fruit, bananas, cocoa and various other palms, oranges, sweet potatoes, etc., etc. The cocoa-nut palm is, of course, most flourishing on the flat coral islands. In the mountainous islands the coast is usually beset with mangroves, which are succeeded inland by fruit trees, and these again, as we ascend, by forests, in which various species of ficus are prominent, myristica (nut$\mathrm{meg}$ ), citrus, eugenia, etc. Ferns also grow in extraordinary luxuriance. 
In regard to the minerals of the five large islands there seems to be no definite information. In Yap the precious metals are reported to have been found.

The people resemble the well-formed, brown, and comparatively intelligent Hawaiians and New Zealanders; but are evidently a mixed race, - Malay, Maori, Negrito, Papuan, and even Chinese and Japanese elements having been detected. Captain Maxwell describes the inhabitants of Strong Island as a most gentle, amiable, and intelligent race, with a complexion lighter than that of the Marshall islanders further to the east. The natives of Ponape, he says, are particularly pleasant and goodlooking, with more refined features than those of any natives he has seen. They do not, however, dress so well as the people of Strong Island, their principal article of clothing being the grass petticoat. The inhabitants of Yap, according to another writer, "are of a comparatively light complexion. The men are tall, and often handsome. They tie their long black hair into a knot, and frequently let it down to amuse themselves with combing it with a long wooden comb. Their bodies are elaborately tattooed. Their legs look as if they were encased in tight pantaloons, and they seem to have on woven vests of a deep-blue tint. The women are lighter in hue than the men, and wear their long black hair in bands. exactly resembling those worn by English ladies from 1830 to 1850 , They cover the backs of their hands and their fore-arms with tattoo marks, so that they appear to have on long woven mitts. Their dress is a short petticoat of shreds of bark reaching below the knee, and their principal decoration white flowers, thrust into the bands of hair that hang in front of their ears. As a rule, both sexes go bareheaded ; but the men occasionally wear a sharp crowned hat of Chinese fashion. As is usual in the Pacific islands, adjacent tribes are at constant feud with each other, and wage war almost continuously with one another in the approved Pacific fashion of murdering stragglers of the opposite party." The total population of the Carolines is not over 20,000, of which Yap alone contributes 8000 , and Ponape 5000.

They are great traders, both among themselves and with Europeans. In Ponape and at Tomil Bay in Yap there are small European trading stations where the natives obtain iron goods, tobacco, spirits, bottles, etc., giving in return trepang and cocoa-nut oil.

They also show considerable constructive power both in house and canoe building. The Yap canoes are of very graceful design, and have curved ornaments at head and stern, which remind the visitor of Venetian gondolas. The natives build enormous houses, roofed in and walled at the sides with mats, and construct stone piers or jetties of great length. Some of their villages are remarkably picturesque. The dwellings stand on mounds of earth, often nearly 100 feet square, the sides of which are cased in with stones. Against these earthen platforms the rich men deposit the extraordinary money which is found, perhaps, only in these islands. "It is composed of large discs of arragonite, often of great size. Six 
feet in diameter, 12 inches in thickness, and an estimated weight of three tons are not uncommon dimensions. The largest known piece is said to be 9 feet 4 inches in diameter, 15 inches thick at the hole in the centre, and 7 inches at the edge. The weight of this was estimated by an American trader, who helped to move it, at four tons and a half. This money is not used as a medium of exchange, but for purposes of ostentation, the richest men being those who can pile most of it against the earthen platforms on which their houses stand, and as a ceremonial present on solemn occasions, like the bits of seventeenth-century European glass called money in the Pelew Islands and the tamboa or whale's teeth of Fiji. The arragonite quarry is in the harbour of Malakat, at Korror Island, in the Pelews. At that place about a hundred Yap men are allowed by King Abba Thoul to reside for the purpose of quarrying the stone."

The language of the Caroline Islanders is hybrid, like the race. The grammatical constructions resemble those of the Maori, but Malay influence is also evident. In some of the islands two languages are in use, the polished and the vulgar, one for addressing superiors and the other for inferiors.

In each group of islands there is a chief who is paramount. In war he has unlimited authority, and exercises it without stint; in time of peace his occupation is gone.

The people have no religion of their own. The nearest approach to it is a belief in the continued activity around them of the spirits of the dead. The lifeless body is held in great respect, and is sacredly preserved until it falls to pieces.

Missionaries were first despatched to the islands in 1710 by the Jesuits of Manila. Nothing, however, was accomplished at that time, for all the members of the mission were massacred on arriving at the Pelews. In modern times two missions have been and are at work, one Spanish Roman Catholic and the other American Protestant. It does not appear that either has as yet had very marked success.

The Carolines have been generally spoken of as belonging to Spain. Text-books of geography and standard works of reference so place them. From all that can be learned, however, Spain never exereised territorial rights in them, or indeed ever had any settlement upon them. In 1875 she proposed to exact duties on goods imported into them, but both England and Germany denied her right, and she refrained. Early in the present year she expressed the intention of sending a couple of vessels to plant her flag on the principal islands of the archipelago, but the intention was not then carried out. Somewhat later, England and Germany indirectly and incidentally showed that they held to their old ground in regard to the claims of Spain; for, in the agreement between these two countries as to the partitioning of New Guinea, there is a clause to the effect that England recognises the paramount importance of German trade in the Caroline and Marshall Islands, and Germany makes the like recognition in regard to English trade in the Ellice, Gilbert, and other 
groups. No such recognitions had any relevancy in a document dealing with the apportionment of the islands of the Pacific, unless as a possible guidance in settling the validity of future annexations. Shortly after this came the news of the hoisting of the German flag on several of the Carolines-news which inflamed the Spaniards and led them to despatch war-vessels to Yap, where German war-vessels also almost simultaneously arrived. Then came diplomatic protests and negotiations, and ultimately the Pope was called in as common friend and arbiter to help in arriving at an amicable settlement of the difficulty. So far as can be at present learned, the result is likely to be a confirmation of the Spanish sovereignty, tempered by important concessions to German commerce.

[A sheet of maps to illustrate the Caroline Islands dispute between Germany and Spain has recently been published by W. \& A. K. Johnston. Detailed accounts of the islands have appeared in the Gazette Géographique, The Times, the Mitteilungen of the Geographical Society of Vienna, and other serials.]

\section{LIEUTENANT A. W. GREELY, UNITED STATES ARMY.}

Honorary Member, Scottish Geographical Society.

Lieutenant Greely, who at the meeting of the Society on November 19th was appointed an Honorary Member of the Society, was born at Newbury Port, Massachusetts, in 1844. At the age of seventeen he enlisted in the Volunteer Army, at the beginning of the civil war in the summer of 1861, and served through several great battles of the rebellion. He was thrice wounded. At the end of the war, he attained the rank of Captain, and was brevetted Major for his services. He was one of the officers selected from the Volunteer Army for retention in the regular service, which he entered with the grade of Lieutenant. In 1868 he was assigned duties in the Signal Officeone of the bureaux of the War Department,- - to which he has since been attached. In connection with the Signal Service, he has also been attached to the staff of General Angus; and he was for some time engaged in constructing, organising, and managing several divisions of the United States military telegraph lines. In 1873 he examined the Mississippi, Missouri, and other great rivers, with the object of determining their characteristics in relation to dangerous floods and overflows. Later, he was employed preparing official weather predictions for the United States, and also in editing and preparing the Office publications in connection with the Signal Service and International Observations.

His appointment as leader of the U.S. Arctic Expedition was made by the late President Garfield. Lieutenant Greely was led to accept this appointment on account of the interest he had always taken in meteorological research in connection with his work in investigating and discussing meteorological observations in the northern hemisphere. 